\title{
Peptidomic analysis of the venom of the solitary bee Xylocopa appendiculata circumvolans
}

\author{
Kohei Kazuma', Kenji Ando', Ken-ichi Nihei ${ }^{1}$, Xiaoyu Wang ${ }^{1}$, Marisa Rangel ${ }^{3,4}$, Marcia Regina Franzolin ${ }^{5}$,
} Kanami Mori-Yasumoto ${ }^{6}$, Setsuko Sekita ${ }^{6},{ }^{2}$ Makoto Kadowaki ${ }^{1}$, Motoyoshi Satake ${ }^{7}$ and Katsuhiro Konno ${ }^{1 *}$

\begin{abstract}
Background: Among the hymenopteran insect venoms, those from social wasps and bees - such as honeybee, hornets and paper wasps - have been well documented. Their venoms are composed of a number of peptides and proteins and used for defending their nests and themselves from predators. In contrast, the venoms of solitary wasps and bees have not been the object of further research. In case of solitary bees, only major peptide components in a few venoms have been addressed. Therefore, the aim of the present study was to explore the peptide component profile of the venom from the solitary bee Xylocopa appendiculata circumvolans by peptidomic analysis with using LC-MS.
\end{abstract}

Methods: A reverse-phase HPLC connected to ESI-OrbiTrap MS was used for LC-MS. On-line mass fingerprinting was made from TIC, and data-dependent tandem mass spectrometry gave MSMS spectra. A major peptide component was isolated by reverse-phase HPLC by conventional way, and its sequence was determined by Edman degradation, which was finally corroborated by solid phase synthesis. Using the synthetic specimen, biological activities (antimicrobial activity, mast cell devaluation, hemolysis, leishmanicidal activity) and pore formation in artificial lipid bilayer were evaluated.

Results: On-line mass fingerprinting revealed that the crude venom contained 124 components. MS/MS analysis gave 75 full sequences of the peptide components. Most of these are related to the major and novel peptide, xylopin. Its sequence, GFVALLKKLPLILKHLH-NH 2 , has characteristic features of linear cationic a-helical peptides; rich in hydrophobic and basic amino acids with no disulfide bond, and accordingly, it can be predicted to adopt an amphipathic a-helix secondary structure. In biological evaluation, xylopin exhibited broad-spectrum antimicrobial activity, and moderate mast cell degranulation and leishmanicidal activities, but showed virtually no hemolytic activity. Additionally, the peptide was able to incorporate pores in artificial lipid bilayers of azolectin, confirming the mechanism of the cytolytic activity by pore formation in biological membranes.

Conclusions: LC-ESI-MS and MS/MS analysis of the crude venom extract from a solitary bee Xylocopa appendiculata circumvolans revealed that the component profile of this venom mostly consisted of small peptides. The major peptide components, xylopin and xylopinin, were purified and characterized in a conventional manner. Their chemical and biological characteristics, belonging to linear cationic a-helical peptides, are similar to the known solitary bee venom peptides, melectin and osmin. Pore formation in artificial lipid bilayers was demonstrated for the first time with a solitary bee peptide.

Keywords: Peptidomic analysis, LC-ESI-MS, Solitary bee, Venom, Linear cationic a-helical peptide

\footnotetext{
*Correspondence: kkgon@inm.u-toyama.ac.jp

'Institute of Natural Medicine, University of Toyama, 2630 Sugitani, Toyama

930-0194, Japan

Full list of author information is available at the end of the article
} 


\section{Background}

Among the hymenopteran insects, the venoms from social wasps and bees - including honeybees, hornets and paper wasps - have been well documented [1, 2]. Their venoms are composed of a number of peptides and proteins and are used for defending their nests and themselves from predators. In contrast, venoms from solitary wasps and bees still require further research. In recent years, we have studied venoms from solitary wasps from Japan and found peptide neurotoxins, antimicrobial and cytolytic peptides and bradykinin-related peptides [3]. However, venoms from solitary bees have never been studied until quite recently.

The first study on solitary bee venoms was published only in 2008 about the European solitary bee Melecta albifrons [4]. A novel peptide, melectin, was isolated and characterized. Melectin has similar characteristics to those of melittin and mastoparan from the honeybee and hornet venoms. It is rich in hydrophobic and basic amino acids, amphipathic properties, and shows antimicrobial, mast cell degranulating and hemolytic activities. Accordingly, this peptide belongs to linear cationic $\alpha$-helical peptides. Since then, studies describing similar solitary bee venom peptides have appeared: osmin [5], panurgine-1 [6], macropin [7], codesane [8], and HYL [9] (Table 1).

These studies describe only the isolation and characterization of major peptides, which comprise a few components of the venom. However, such venoms consist of a complex mixture of many constituents, which cooperatively act for the venom toxicity and biological functionality. Accordingly, in order to know the exact nature of a venom, the chemical characterization of whole components may be important. In this viewpoint, we investigated the peptide component profile of the venom of Xylocopa appendiculata circumvolans, a solitary bee inhabiting in Japan, by peptidomic analysis using liquid chromatography-electrospray ionizationmass spectrometry (LC-ESI-MS) [5, 10]. Furthermore, we isolated two major peptides, designated xylopin and xylopinin, and found that they belong to linear cationic

Table 1 Solitary bee venom peptides

\begin{tabular}{ll}
\hline Melectin & GFLSILKKVLPKVMAHMK-NH \\
Osmin & GFLSALKKYLPIVLKHV-NH \\
Panurgine-1 & LNWGAILKHIIK-NH 2 \\
Macropin & GFGMALKLLKKVL-NH ${ }_{2}$ \\
Codesane & GMASLLAKVLPHWKLIK-NH 2 \\
HYL & GIMSSLMKKLAAHIAK-NH ${ }_{2}$ \\
Xylopin & GFVALLKKLPLILKHLH-NH ${ }_{2}$ \\
Xylopinin & GFVALLKKLPLILKHLP-NH $\mathrm{NH}_{2}$ \\
\hline
\end{tabular}

$\alpha$-helical peptides. Biological characterization of xylopin revealed that it is an antimicrobial and cytolytic peptide.

\section{Methods \\ LC-ESI-MS}

The crude venom was analyzed with a LC (Accela 600 Pump, Thermo Scientific) connected with ESI-FTMS (LTQ Orbitrap XL, Thermo Scientific). About 10\% of crude venom from a single specimen diluted in $10 \mu \mathrm{L}$ of water was subjected to reversed-phase HPLC using CAPCELL PAK $\mathrm{C}_{18}$ UG 120, $1.5 \times 150 \mathrm{~mm}$ (Shiseido Co., Ltd., Japan) with linear gradient from $5 \%$ to $65 \%$ $\mathrm{CH}_{3} \mathrm{CN} / \mathrm{H}_{2} \mathrm{O} / 0.1 \%$ formic acid at a flow rate of $200 \mu \mathrm{L} /$ min over $20 \mathrm{~min}$ at $25{ }^{\circ} \mathrm{C}$. ESI-FTMS was operated by Xcalibar software (Thermo Scientific) as: capillary voltage, + $4.6 \mathrm{kV}$; capillary temp., $350{ }^{\circ} \mathrm{C}$; sheath and aux gas flow, 50 and 30, respectively (arbitrary units). MS/ MS spectra were obtained by data dependent MS/MS mode (two most intense peaks by HCD) and the obtained spectra were manually analyzed to give peptide sequences, which were confirmed by MS-Product in ProteinProspector program (http://prospector.ucsf.edu/ prospector/cgi-bin/msform.cgi?form $=$ msproduct).

\section{MALDI-TOF MS}

MALDI-TOF MS spectra were acquired on an Autoflex TOF/TOF mass spectrometer (Bruker Daltonics, Japan) equipped with $337 \mathrm{~nm}$ pulsed nitrogen laser under reflector mode. The accelerating voltage was $20 \mathrm{kV}$. Matrix, $\alpha$-cyano-4-hydroxycinnamic acid (Aldrich), was prepared at a concentration of $10 \mathrm{mg} / \mathrm{mL}$ in $1: 1$ $\mathrm{CH}_{3} \mathrm{CN} / 0.1 \%$ TFA. External calibration was performed with [Ile ${ }^{7}$ ]-angiotensin III $(m / z$ 897.51, monoisotopic, Sigma) and human ACTH fragment 18-39 ( $\mathrm{m} / \mathrm{z}$ 2465.19, monoisotopic, Sigma). The sample solution $(0.5 \mu \mathrm{L})$ dropped onto the MALDI sample plate was added to the matrix solution $(0.5 \mu \mathrm{L})$ and allowed to dry at room temperature. For TOF/TOF measurement, argon was used as a collision gas and ions were accelerated at $19 \mathrm{kV}$. The series of $b$ and $y$ ions were afforded, which enabled identification of whole amino acid sequence by manual analysis.

\section{Purification}

Female bees of Xylocopa appendiculata circumvolans were collected at Kami-ichi, Toyama in Japan. The venom sacs from five individuals were dissected immediately after collection and extracted with 1:1 acetonitrilewater containing $0.1 \%$ TFA $\left(\mathrm{CH}_{3} \mathrm{CN} / \mathrm{H}_{2} \mathrm{O} / 0.1 \%\right.$ TFA), and lyophilized.

The lyophilized extracts were subjected to reversedphase HPLC (Shimadzu Corp., Japan) using CAPCELL PAK $\mathrm{C}_{18}, 6 \times 150 \mathrm{~mm}$ (Shiseido Co., Ltd., Japan) with a linear gradient from $5 \%$ to $65 \% \mathrm{CH}_{3} \mathrm{CN} / \mathrm{H}_{2} \mathrm{O} / 0.1 \%$ TFA 
at a flow rate of $1 \mathrm{~mL} / \mathrm{min}$ over $30 \mathrm{~min}$ (Fig. 1). This process released xylopin and xylopinin eluted at $25.1 \mathrm{~min}$ and $26.0 \mathrm{~min}$, respectively.

\section{Amino acid sequencing}

Automated Edman degradation was performed by a gasphase protein sequencer PPSQ-10 (Shimadzu Corp., Japan).

\section{Peptide synthesis}

Peptides were synthesized on an automated PSSM-8 peptide synthesizer (Shimadzu Corp., Japan) by stepwise solid-phase method using N-9-fluorenylmethoxycarbonyl (Fmoc) chemistry. All the resins and Fmoc-L-amino acids were purchased from HiPep Laboratories (Kyoto, Japan). Cleavage of the peptide from the resin was achieved by treatment with a mixture of TFA $/ \mathrm{H}_{2} \mathrm{O} /$ triisopropylsilane (TIS) $(95: 2.5: 2.5)$ at room temperature for $2 \mathrm{~h}$. After removal of the resin by filtration and washing twice with TFA, the combined filtrate was added dropwise to diethyl ether at $0{ }^{\circ} \mathrm{C}$ and then centrifuged at $3000 \mathrm{rpm}$ for $10 \mathrm{~min}$. Thus, obtained crude synthetic peptide was purified by semipreparative reverse-phase HPLC using CAPCELL PAK $\mathrm{C}_{18}, 10 \times 250 \mathrm{~mm}$ with isocratic elution of $40-60 \% \mathrm{CH}_{3} \mathrm{CN} / \mathrm{H}_{2} \mathrm{O} / 0.1 \%$ TFA at a flow rate of $3 \mathrm{~mL} / \mathrm{min}$. The homogeneity and the sequence were confirmed by MALDI-TOF MS $[\mathrm{m} / \mathrm{z} \quad 1939.1$ $\left.(\mathrm{M}+\mathrm{H})^{+}\right]$and analytical HPLC (co-eluted with natural peptide by using CAPCELL PAK $\mathrm{C}_{18}, 6 \times 150 \mathrm{~mm}$ with isocratic elution of $45 \% \mathrm{CH}_{3} \mathrm{CN} / \mathrm{H}_{2} \mathrm{O} / 0.1 \%$ TFA at a flow rate of $1 \mathrm{~mL} / \mathrm{min}$ ).

\section{Antimicrobial activity (determination of minimal inhibitory concentration, MIC)}

The microorganisms used in this study were: Staphylococcus aureus ATCC 25923; Micrococcus luteus ATCC 10240; Bacillus subtilis ATCC 6633; clinical isolates of: Staphylococcus epidermidis, Streptococcus pyogenes, Streptococcus agalactiae, Enterococcus faecalis, Enterococcus faecium; Escherichia coli ATCC 25922; clinical isolates of: Shigella boydii, Klebsiella pneumoniae, Enterobacter cloacae, Proteus mirabilis, Morganella morgannii; Pseudomonas aeruginosa ATCC 27853; Stenotrophomonas maltophilia ATCC 13637; Acinetobacter baumanii/calcoaceticus (clinical isolate); Saccharomyces cerevisae and Candida albicans ATCC 90112.

The MICs of the tested peptide were determined in the following form: $50 \mu \mathrm{L}$ of bacterial suspension $\left(10^{6} \mathrm{CFU} / \mathrm{mL}\right)$ in each well of a 96-well microtitre plates were incubated at $37{ }^{\circ} \mathrm{C}$ for $18 \mathrm{~h}$ with various concentration of $50 \mu \mathrm{L}$ of the peptide solution, resulting in a final volume of $100 \mu \mathrm{L}$ with $10^{4} \mathrm{CFU} /$ well, according CLSI [11]. Following incubation, microbial growth was measured by monitoring the optical density (OD) increase at $595 \mathrm{~nm}$ in an ELISA reader (Multiskan ${ }^{\circ}$ EX Thermo Fisher Scientific, EUA). The results were expressed as inhibition percentage of OD against a control (microorganisms in the absence of peptide). In addition, the

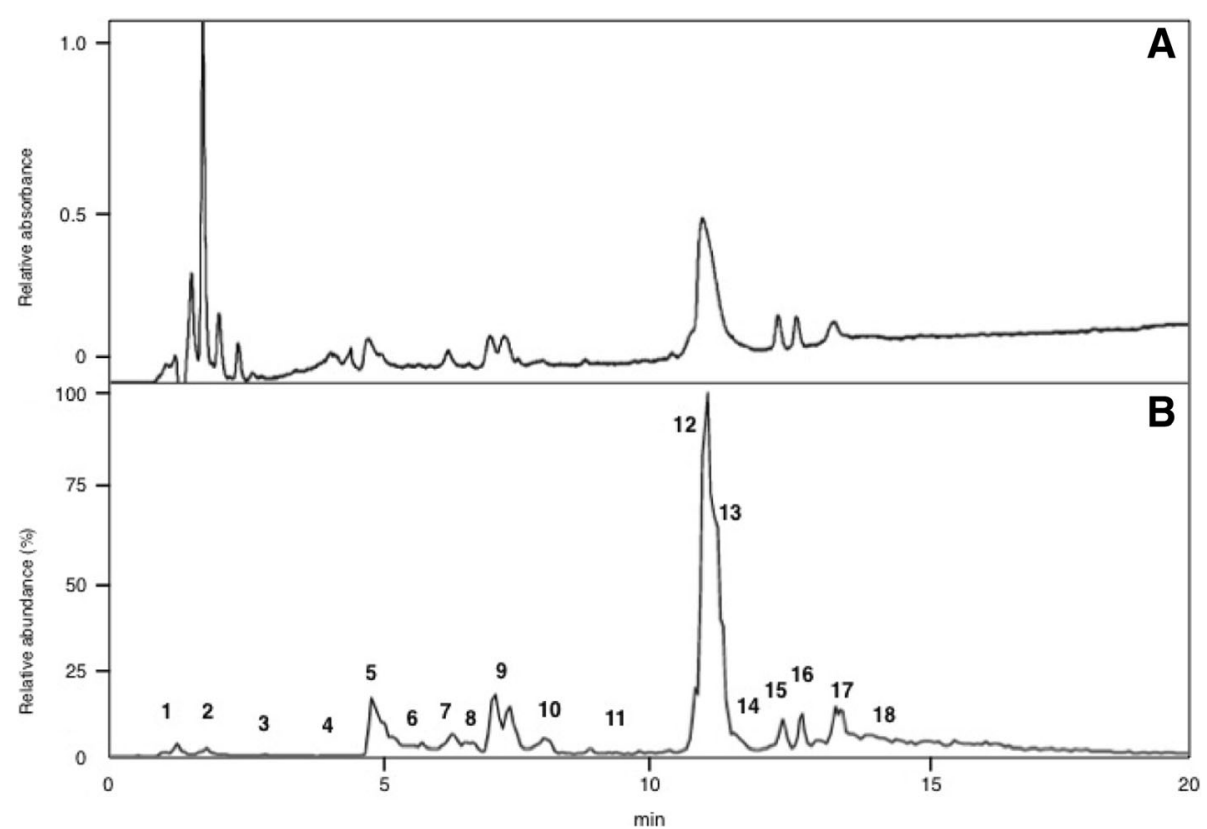

Fig. 1 LC-ESI-MS profile of crude venom extracts of Xylocopa appendiculata circumvolans. About 10\% of crude venom extract of a single specimen was subjected to reverse-phase HPLC using CAPCELL PAK $\mathrm{C}_{18}(1.5 \times 150 \mathrm{~mm})$ with linear gradient of $5-65 \% \mathrm{CH}_{3} \mathrm{CN} / \mathrm{H}_{2} \mathrm{O} / 0.1 \%$ formic acid over 20 min at flow rate of $200 \mu \mathrm{L} / \mathrm{min}$. a UV absorption by PDA. b Total ion current (TIC). Numbers in B show "virtual" fraction number as in Tables 2 to 6 
lowest concentration of peptide at which there is no visible growth after overnight incubation was observed.

\section{Mast cell degranulating activity}

The ability of the peptides to induce mast cell degranulation was investigated in vitro using the protocol of quantification of the granular enzyme $\beta$-hexosaminidase released in the supernatants of PT18 cells (a connective tissue-type mast cell model) and RBL-2H3 cells (a mucosal-type mast cell model), according to Ortega et al. [12]. For this, $4 \times 10^{6}$ PT18 cells or $1.2 \times 10^{5}$ RBL-2H3 cells $(200 \mu \mathrm{L})$ were incubated in the presence of the peptides for $30 \mathrm{~min}$ in Tyrode's solution at $37{ }^{\circ} \mathrm{C} / 5 \% \mathrm{CO}_{2}$. After this, the cells were centrifuged and the supernatants were collected. The cells incubated only with the Tyrode's solution were lysed with $200 \mu \mathrm{L}$ of $0.5 \%$ Triton X-100 (Sigma-Aldrich) solution to evaluate the total enzyme content. From each experimental sample to be assayed, four aliquots $(10 \mu \mathrm{L})$ of the supernatant were taken to separate microwell plates. To these samples, $90 \mu \mathrm{L}$ of the substrate solution containing $1.3 \mathrm{mg} / \mathrm{mL}$ of $\mathrm{p}$-nitrophenyl$\mathrm{N}$-acetyl- $\beta$-D-glucosamine (Sigma Chemical Co.) in $0.1 \mathrm{M}$ citrate, $\mathrm{pH} 4.5$, was added and the plates incubated for $12 \mathrm{~h}$ at $37^{\circ} \mathrm{C}$. The reactions were stopped by addition

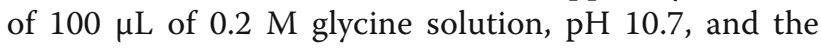
optical density determined at $405 \mathrm{~nm}$ in an ELISA reader (Labsystems Multiskan Ex). The extent of secretion was expressed as the net percentage of the total $\beta$-hexosaminidase activity in the supernatant of unstimulated cells. The results represent the mean of quadruplicate tests \pm standard deviation (SD).

\section{Hemolytic activity}

The use of mice in this assay was in agreement with the Ethical Principles in Animal Research adopted by the Brazilian College of Animal Experimentation and was approved by the Ethical Committee for Animal Research of Butantan Institute (protocol no. 459/08).

To evaluate the pore-forming interaction of the peptide with biological murine membranes, a hemolytic assay was performed. A 4\% suspension of mouse erythrocytes (ES) was prepared as previously described [13, 14]. Different concentrations of the peptide were incubated with the ES at room temperature $\left( \pm 22{ }^{\circ} \mathrm{C}\right)$ in an ELISA plate $(96$ wells) for $1 \mathrm{~h}$ and centrifuged (1000×g for $5 \mathrm{~min}$ ). The hemolytic activity of the supernatant was measured by the absorbance at $540 \mathrm{~nm}$ using the absorbance of the Krebs-Henseleit physiological solution (in $\mathrm{mM}: \mathrm{NaCl}$, 113; $\mathrm{KH}_{2} \mathrm{PO}_{4}, 1.2 ; \mathrm{KCl}, 4 ; \mathrm{MgSO}_{4}, 1.2 ; \mathrm{CaCl}_{2}, 2.5$; $\mathrm{NaHCO}_{3}, 25$; and glucose, 11.1), which was the vehicle for the peptide, as a blank. Total hemolysis was obtained with $1 \%$ Triton X-100, and the percentage of hemolysis was calculated relative to this value.

\section{Leishmanicidal activity}

Medium 199 was used for the cultivation of promastigote forms of Leishmania major (MHOM/SU/73/ $5 \mathrm{ASKH})$. Promastigotes were cultured in the medium [supplemented with heat-inactivated $\left(56{ }^{\circ} \mathrm{C}\right.$ for $30 \mathrm{~min}$ ) fetal bovine serum (10\%)] at $27{ }^{\circ} \mathrm{C}$, in a $5 \% \mathrm{CO}_{2}$ atmosphere in an incubator [15].

The leishmanicidal effects of the peptides were assessed using the improved 3-[4,5-dimethylthiazol-2-yl]-2,5-diphenyltetrazolium bromide (MTT assay) method as follows. Cultured promastigotes were seeded at $4 \times 10^{5} / 50 \mathrm{~mL}$ of the medium per well in 96-well microplates. Then, $50 \mathrm{~mL}$ of different concentrations of test compounds dissolved in a mixture of DMSO and the medium were added to each well. Each concentration was tested in triplicate. The microplate was incubated at $27{ }^{\circ} \mathrm{C}$ in $5 \% \mathrm{CO}_{2}$ for $48 \mathrm{~h}$. TetraColor ONE $(10 \mathrm{~mL})$ a mixture of 2-(2-methoxy-4-nitrophenyl)-3-(4-nitrophenyl)-5(2,4-disulfophenyl)- $2 \mathrm{H}$-tetrazolium,monosodium salt and 1-methoxy-5-methylphenazinium methosulfate was added to each well and the plates were incubated at $27{ }^{\circ} \mathrm{C}$ for $6 \mathrm{~h}$. Optical density values (test wavelength $450 \mathrm{~nm}$; reference wavelength $630 \mathrm{~nm}$ ) were measured using a microplate reader (Thermo BioAnalysis Japan Co., Ltd.). The values of $50 \%$ inhibitory concentration of the peptides were estimated from the dose-response curve.

\section{Channel-like incorporation in mimetic lipid bilayers}

The experiments were performed with the automated Patch-Clamp device Port-a-Patch (Nanion Technologies, Germany), using borosilicate glass chips NPC-1 with aperture diameter of approximately $10 \mu \mathrm{m}$. The resistance of the apertures was approximately $1 \mathrm{M} \Omega$ in $500 \mathrm{mM} \mathrm{KCl}$ solution. Current signals resulting from pore formation were amplified by EPC-10 amplifier (Heka Elektronik, Lambrecht, Germany) and recorded in computer after conversion performed by an analogical/ digital interface ITC-1600. The system was computer controlled by the PatchControl ${ }^{\mathrm{Tw}}$ software (Nanion) $[16,17]$.

Symmetrical solutions of 150 or $500 \mathrm{mM} \mathrm{KCl}$ with $5 \mathrm{mM}$ Tris were used. Asolectin (Sigma), a negatively charged mixture of lipids, was used to form artificial membranes. Asolectin was dissolved in $\mathrm{n}$-decane at a concentration of $2 \mathrm{mg} / \mathrm{mL}$. The bilayers were painted onto the aperture of the chip using disposable polypropylene pipet tips. Measurements of the capacitive currents evoked by control voltage pulses and increase in the membrane resistance indicated the formation of bilayers. After the formation of a lipid bilayer $(\mathrm{Rm}>1$ $\mathrm{G} \Omega$ ), xylopin diluted with Milli-Q water at a $10 \mu \mathrm{M}$ concentration was added to the cis side of the chip (top) to observe the single channel activity. The volume of peptide solution was never superior to $10 \%$ of the solution at the cis side. Voltage pulses were applied at the trans 
side of the chip (bottom). Usually, single channel activity started approximately $10 \mathrm{~min}$ after adding the peptide, as monitored by a constant $\mathrm{V}_{\text {hold }}$ of $-100 \mathrm{mV}$ or $100 \mathrm{mV}$. Pore conductance of incorporated channels was determined under positive and negative voltage pulses $\left(\mathrm{V}_{\text {hold }}\right)$. The experiments were performed at room temperature $\left(\sim 22{ }^{\circ} \mathrm{C}\right)$. The data were analyzed by PatchMaster and Matlab softwares.

\section{Results}

\section{On-line mass fingerprinting}

LC-ESI-MS profile is shown in Fig. 1. The volume of peptide solution never exceeded $10 \%$ of the amount of crude venom from a single specimen, which is sufficient for LC-ESI-MS analysis (mass fingerprinting and peptide sequencing). On-line mass fingerprint was prepared from TIC by "virtual fractionation", collecting MS spectra from a certain range of retention time, and then, the molecular mass was analyzed in each fraction. The results are summarized in Table 2. A total of 124 molecular mass peaks were found from 18 virtual fractions. The low molecular mass components $(\mathrm{m} / \mathrm{z} 100-300)$ are free amino acids, biogenic amines and nucleic acids (data not shown) and those of $\mathrm{m} / \mathrm{z}$ range from 500 to 4000 should be peptides, in particular, $\mathrm{m} / \mathrm{z}$ from 500 to 2000 accounts for $60 \%$, implying that a majority of components in this venom are relatively small peptides.

\section{Peptide sequencing by MS/MS analysis}

Data dependent MS/MS measurement afforded MS/ MS spectra from 79 peptide molecules. Manual sequence analysis of these MS/MS spectra revealed the full sequence of 58 peptides, and the rest of the 21 peptides were only partially sequenced (data not shown). The analyzed full sequences are shown in Table 3.

These sequences can be classified according to homology and similarity. Most of them are related to the major peptide xylopin (mentioned below). As shown in Table 4, most of them are truncated peptides from both $\mathrm{N}$ - and $\mathrm{C}$-terminus, in other words, they have a partial structure of xylopin. Seemingly, these truncated peptides are cleavage products of xylopin in some way, but it is not sure whether they are originally contained in the venom or not. Table 5 summarizes the peptides that have a similar partial sequence to xylopin as well, but no amidated $\mathrm{C}$-terminus and have $\mathrm{G}$ (glycine) at the $\mathrm{C}$-terminus instead. They are clearly the precursors of amidated C-terminus counterparts because the C-terminal amidation (post-translational modification) takes place by oxidation-hydrolysis of C-terminal $\mathrm{G}$ (glycine) residue.

The rest of the peptides in this venom may be new peptides as summarized in Table 6. All these have no homology to any known peptides.

Table 2 Mass fingerprint of crude venom from $X$. appendiculata circumvolans

\begin{tabular}{|c|c|c|}
\hline Fraction no. & Retention time (min) & {$[\mathrm{M}+\mathrm{H}]^{+} \mathrm{m} / \mathrm{z}$} \\
\hline 1 & $1.0-1.5$ & $116.071,175.119,184.073,348.071,381.080,405.236,441.101$ \\
\hline 2 & $1.5-2.0$ & $132.102,268.104,322.077,377.058,733.323,759.499$ \\
\hline 3 & $2.0-3.0$ & $284.099,373.281,437.051,469.277,654.357,817.504,947.484,1002.508$ \\
\hline 4 & $3.0-4.2$ & $182.117,431.214,598.428,937.390,1368.747$ \\
\hline 5 & $4.2-5.0$ & $623.423,646.423,1517.714,2064.031$ \\
\hline 6 & $5.0-6.0$ & $930.588,969.653,1165.500,1189.459,1338.913,1306.915,1715.808,2807.314$ \\
\hline 7 & $6.0-6.4$ & $322.176,393.214,961.656,1210.815,1451.994,1925.941$ \\
\hline 8 & $6.4-7.0$ & $714.306,1211.799,1268.821,1336.563,1510.001,3225.624,3243.642$ \\
\hline 9 & $7.0-8.0$ & $\begin{array}{l}\text { 637.346, 715.291, 793.482, 838.421, 875.527, 1082.720, 1178.861, 1337.549, } \\
1565.078,1636.116,2064.036,3400.643\end{array}$ \\
\hline 10 & $8.0-9.0$ & $\begin{array}{l}\text { 690.456, 747.477, 908.509, 933.515, 937.678, 1249.897, 1427.606, 1608.000, 1626.012, } \\
1694.121,2065.019,3187.725,3245.730\end{array}$ \\
\hline 11 & $9.0-10.0$ & $\begin{array}{l}379.114,506.298,696.502,761.492,988.656,1021.593,1085.709,1366.821,1384.832, \\
1882.253,3187.723,3245.728\end{array}$ \\
\hline 12 & $10.0-10.8$ & $370.199,941.598,1690.115,1735.185,1939.274$ \\
\hline 13 & $10.8-11.4$ & $619.381,926.118,1553.055,1783.363,1997.276$ \\
\hline 14 & $11.4-12.0$ & $1311.877,1803.199,1899.267,2087.312,2139.353,2236.641,3087.760,3256.821$ \\
\hline 15 & $12.0-12.7$ & $680.314,704.272,1424.961,1956.252,2121.345,2197.359,2281.379,2648.565$ \\
\hline 16 & $12.7-13.2$ & $2095.280,2113.292$ \\
\hline 17 & $13.2-13.6$ & $662.303,1316.450,2077.267,2153.287,2171.297$ \\
\hline 18 & $13.6-15.0$ & $1709.063,3860.509,4015.525$ \\
\hline
\end{tabular}


Table 3 Peptide sequences analyzed from MS/MS spectra

\begin{tabular}{|c|c|c|c|c|c|}
\hline Fraction no. & {$[\mathrm{M}+\mathrm{H}]^{+}$} & Sequence & Fraction no. & {$[\mathrm{M}+\mathrm{H}]^{+}$} & Sequence \\
\hline \multirow[t]{9}{*}{1} & 405.236 & $\mathrm{HLH}-\mathrm{NH}_{2}$ & 9 & 637.346 & FAFPR \\
\hline & & & & 793.482 & FLVSSLK \\
\hline & & & & 838.421 & SNFAFPR \\
\hline & & & & 875.527 & GFVALLKK \\
\hline & & & & 1082.720 & LPLILKHLH-NH ${ }_{2}$ \\
\hline & & & & 1178.861 & LLKKLPLILK \\
\hline & & & & 1337.549 & DGLDEYEPEDR \\
\hline & & & & 1565.078 & LLKKLPLILKHLH-NH ${ }_{2}$ \\
\hline & & & & 1636.116 & ALLKKLPLILKHLH-NH ${ }_{2}$ \\
\hline \multirow[t]{6}{*}{2} & 759.499 & ILKHLH-NH${ }_{2}$ & 10 & 690.456 & FVALLK \\
\hline & & & & 747.477 & GFVLKK \\
\hline & & & & 908.509 & DFLVSSLK \\
\hline & & & & 937.678 & LKKLPLIL \\
\hline & & & & 1249.897 & ALLKKLPLILK \\
\hline & & & & 1694.121 & ALLKKLPLILKHLHG \\
\hline \multirow[t]{6}{*}{3} & 373.281 & ILK & 11 & 506.298 & GFVAL \\
\hline & 469.277 & HVLT & & 696.502 & PLKLI \\
\hline & 817.504 & ILKHLHG & & 988.656 & GFVALLKKL \\
\hline & 947.489 & EMKSVEPK & & 1021.593 & LDFLVSSLK \\
\hline & & & & 1085.709 & GFVALLKKLP \\
\hline & & & & 1882.253 & FVALLKKLPLILKH \\
\hline \multirow[t]{3}{*}{4} & 431.214 & SVEP & 12 & 1690.115 & GFVALLKKLPLILKH \\
\hline & 598.428 & LKKLP & & 1735.185 & VALLKKLPLILKHLH-NH ${ }_{2}$ \\
\hline & 937.390 & EYEPEDR & & 1939.274 & GFVALLKKLPLILKHLH-NH ${ }_{2}$ \\
\hline \multirow[t]{3}{*}{5} & 623.423 & LILKH & 13 & 619.381 & GFVALL \\
\hline & 646.413 & LVSSLK & & 1553.055 & GFVALLKKLPLILK \\
\hline & & & & 1997.276 & GFVALLKKLPLILKHLKG \\
\hline \multirow[t]{5}{*}{6} & 930.588 & LILKHLHG & 14 & 1311.877 & GFVALLKKLPLI \\
\hline & 969.653 & PLILKHLH-NH ${ }_{2}$ & & 1803.199 & GFVALLKKLLPLILKHL \\
\hline & 1165.500 & LDEYEPEDR & & 1899.267 & GFVALLKKLPLILKHLP-NH ${ }_{2}$ \\
\hline & 1338.913 & KKLPLILKHLH-NH ${ }_{2}$ & & 2139.353 & EAGFVALLKKLPLILKHLH-NH ${ }_{2}$ \\
\hline & 1396.915 & KKLPLILKHLHG & & & \\
\hline \multirow[t]{5}{*}{7} & 322.176 & GFV & 15 & 1424.961 & GFVALLKKLPLIL \\
\hline & 393.214 & GFVA & & & \\
\hline & 961.656 & KLPLILKH & & & \\
\hline & 1210.815 & KLPLILKHLH-NH & & & \\
\hline & 1451.994 & LKKLPLILKHLH-NH ${ }_{2}$ & & & \\
\hline \multirow[t]{4}{*}{8} & 1211.799 & KLPLILIKHLH & & & \\
\hline & 1268.821 & KLPLILKHLHG & & & \\
\hline & 1336.563 & NGLDEYEPEDR & & & \\
\hline & 1500.001 & LKKLPLILKHLHG & & & \\
\hline
\end{tabular}


Table 4 Peptides related to xylopin

\begin{tabular}{|c|c|c|}
\hline Fraction no. & {$[\mathrm{M}+\mathrm{H}]^{+}$} & Sequence \\
\hline 7 & 322.176 & GFV \\
\hline 7 & 393.214 & GFVA \\
\hline 11 & 506.502 & GFVAL \\
\hline 13 & 619.381 & GFVALL \\
\hline 10 & 747.477 & GFVALLK \\
\hline 9 & 875.527 & GFVALLKK \\
\hline 11 & 988.656 & GFVALLKKL \\
\hline 11 & 1085.709 & GFVALLKKLP \\
\hline 14 & 1311.877 & GFVALLKKLPLI \\
\hline 15 & 1424.961 & GFVALLKKLPLIL \\
\hline 13 & 1553.055 & GFVALLKKLPLILK \\
\hline 12 & 1690.115 & GFVALLKKLPLILKH \\
\hline 14 & 1803.199 & GFVALLKKLPLILKHL \\
\hline 3 & 373.281 & ILK \\
\hline 5 & 623.423 & LILKH \\
\hline 7 & 961.656 & KLPLILKH \\
\hline 8 & 1211.799 & KLPLILKHLH \\
\hline 9 & 1178.861 & LLKKLPLILK \\
\hline 10 & 690.456 & FVALLK \\
\hline 10 & 1249.897 & ALLKKLPLILK \\
\hline 10 & 937.678 & LKKLPLILK \\
\hline 11 & 696.502 & LPLILK \\
\hline 1 & 405.236 & $\mathrm{HLH}-\mathrm{NH}_{2}$ \\
\hline 2 & 759.499 & ILKHLH-NH 2 \\
\hline 6 & 969.653 & PLILKHLH-NH 2 \\
\hline 9 & 1082.720 & LPLILKHLH-NH 2 \\
\hline 7 & 1210.815 & KLPLILKHLH-NH \\
\hline 6 & 1338.913 & KKLPLILKHLH-NH ${ }_{2}$ \\
\hline 7 & 1451.994 & LKKLPLILKHLH-NH ${ }_{2}$ \\
\hline 9 & 1565.078 & LLKKLPLILKHLH-NH ${ }_{2}$ \\
\hline 9 & 1636.116 & ALLKKLPLILKHLH-NH ${ }_{2}$ \\
\hline 12 & 1735.185 & VALLKKLPLILKHLH-NH ${ }_{2}$ \\
\hline 11 & 1882.253 & FVALLKKLPLILKHLH-NH \\
\hline 14 & 1899.267 & GFVALLKKLPLILKHLP-NH \\
\hline 12 & 1939.274 & GFVALLKKLPLILKHLH-NH ${ }_{2}^{\mathrm{b}}$ \\
\hline 19 & 2139.353 & EAGFVALLKKLPLILKHLH-NH \\
\hline
\end{tabular}

Purification and sequence determination of major peptides

Two major peptides, called xylopin and xylopinin, were purified by reversed-phase HPLC (Fig. 2). The primary sequence of xylopin was determined by Edman degradation as GFVALLKKLPLILKHLH, which corresponded to a peptide component with $m / z 1939.274(\mathrm{M}+\mathrm{H})^{+}$in the crude venom, and accordingly, the C-terminus is
Table 5 Peptides without amidated C-terminus

\begin{tabular}{lll}
\hline Fraction no. & {$\left[\mathrm{M}+\mathrm{H}^{+}\right.$} & Sequence \\
\hline 3 & 817.504 & ILKHLHG \\
6 & 930.588 & LILKHLHG \\
8 & 1268.821 & KLPLILKHLHG \\
6 & 1396.915 & KKLPLILKHLHG \\
8 & 1510.001 & LKKLPLILKHLHG \\
10 & 1694.121 & ALLKKLPLILKHLHG \\
13 & 1997.276 & GFVALLKKLPLILKHLHG \\
\hline
\end{tabular}

amidated. The solid-phase synthesis of this peptide and the HPLC comparison of the synthetic specimen with the natural peptide finally corroborated the sequence.

The sequence of xylopinin was determined by MALDI-TOF/TOF analysis as GFVALLKKLPLILKHLP$\mathrm{NH}_{2}$, in which $\mathrm{L}$ and I were differentiated by $w$ and $d$ ions, and corresponded to the peptide with $\mathrm{m} / \mathrm{z}$ $1899.267(\mathrm{M}+\mathrm{H})^{+}$in the crude venom.

The chemical features of xylopin and xylopinin, rich in hydrophobic and basic amino acids with no disulfide bond, are characteristic of linear cationic cytolytic peptides [18]. The known solitary bee venom peptides, melectin and osmin, can be included in this type of peptides, and are highly homologous to these new peptides. This class of peptides has been known to adopt an amphipathic $\alpha$-helical conformation, showing an amphiphilic character under appropriate conditions [19-22], and the amphipaticity of peptides has been considered essential for their biological activities [23]. In fact, if the helical wheel projection of xylopin and xylopinin sequences were drawn, amphipathic $\alpha$-helical conformations would be depicted as in Fig. 3. Based on this view,

Table 6 Unknown peptides

\begin{tabular}{lll}
\hline Fraction no. & {$\left[\mathrm{M}+\mathrm{H}^{+}\right.$} & Sequence \\
\hline 3 & 469.277 & HVLT \\
3 & 654.357 & EVLSAH-NH 2 \\
4 & 431.214 & SVEP \\
3 & 947.484 & EMKSVEPK \\
9 & 637.346 & FAFPR \\
9 & 838.421 & SNFAFPR \\
5 & 646.413 & LVSSLK \\
9 & 793.482 & FLVSSLK \\
10 & 908.509 & DFLVSSLK \\
11 & 1021.593 & LDFLVSSLK \\
4 & 937.390 & EYEPEDR \\
6 & 1165.500 & LDEYEPEDR \\
8 & 1336.563 & NGLDEYEPEDR \\
9 & 1337.549 & DGLDEYEPEDR \\
\hline
\end{tabular}




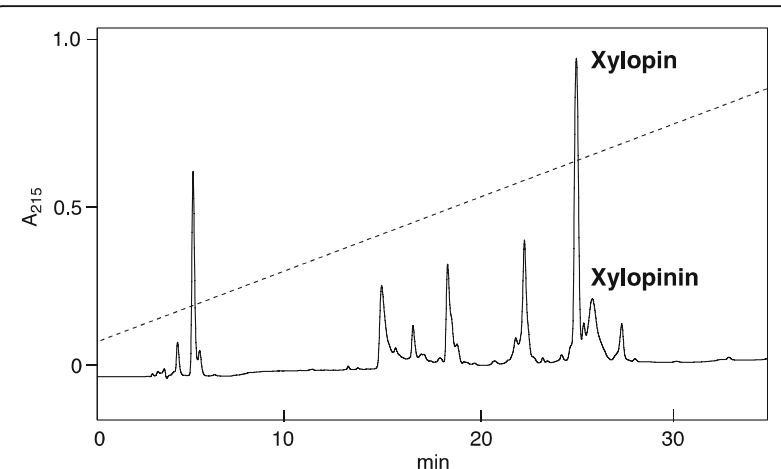

Fig. 2 Fractionation of venom extracts of Xylocopa appendiculata circumvolans by reverse-phase HPLC using CAPCELL PAK $C_{18}$ $(6 \times 150 \mathrm{~mm})$ with linear gradient of $5-65 \% \mathrm{CH}_{3} \mathrm{CN} / \mathrm{H}_{2} \mathrm{O} / 0.1 \%$ TFA over $30 \mathrm{~min}$ at flow rate of $1 \mathrm{~mL} / \mathrm{min}$. UV absorption was monitored at $215 \mathrm{~nm}$

all the hydrophilic amino acid residues, $\mathrm{S}, \mathrm{H}$ and $\mathrm{K}$, are located on one side, whereas the hydrophobic amino acid residues, A, F, I, L and V are on the other side of the helix.

\section{Biological activities}

Biological activities of xylopin were evaluated by using synthetic specimen. The mast cell degranulation, hemolysis, antimicrobial and antiprotozoan (leishmanicidal) activities were tested because these are characteristic biological activities for these types of peptide.

Mast cell degranulation activity on RBL-2H3 cells was similar to mastoparan at low concentrations $(<30 \mu \mathrm{M})$, whereas at higher concentrations $(100 \mu \mathrm{M})$, it was more potent than mastoparan (Fig. 4). Antimicrobial activity can be considered strong and of broad spectrum, with MICs from 1.9 to $15 \mu \mathrm{M}$. The peptide showed the lowest MIC values against gram-positive bacteria, with exception of S. aureus ATCC25923 and Enterococcus spp., and presented potent activities against yeasts (Table 7). Hemolytic activity against mouse erythrocytes, however,

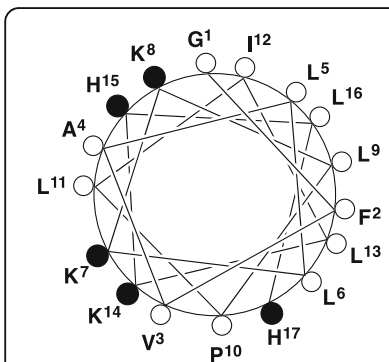

Xylopin

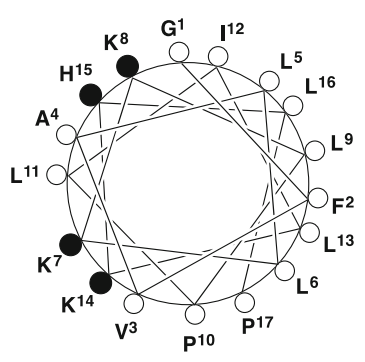

Xylopinin
Fig. 3 Helical wheel projection of the sequence of xylopin and xylopinin. In this view through the helix axis, the hydrophilic $\mathrm{His}(\mathrm{H})$ and Lys $(K)$ residues are located on one side and the hydrophobic Ala (A), Phe (F), lle (I) and Leu (L) residues on the other side of the helix

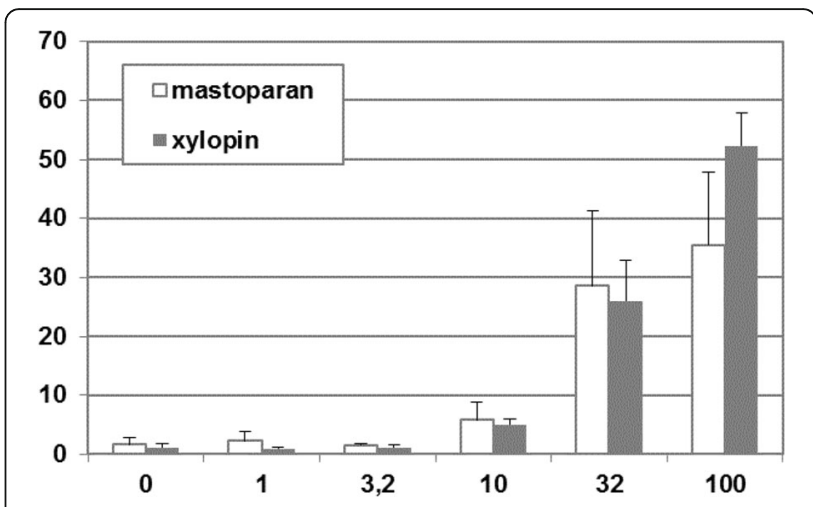

Fig. 4 The degranulation in RBL-2H3 cells (a mucosal-type mast cell model) measured by the $\beta$-hexosaminidase release, basal and after treatment with xylopin, the novel venom peptide from the solitary bee Xylocopa appendiculata circumvolans. Concentrations are in $\mu \mathrm{M}$ and data represent the mean from two to four independent experiments

was low, reaching only $30 \%$ at the highest concentration of $1 \mathrm{mM}$. Xylopin showed significant leishmanicidal activity with an $\mathrm{IC}_{50}$ of $25 \mu \mathrm{M}$ against Leishmania major.

\section{Channel-like incorporation in mimetic lipid bilayers}

Xylopin induced pore formation in painted asolectin artificial lipid bilayers at $1 \mu \mathrm{M}$ concentration. The apertures occurred when voltage was clamped at either

Table 7 Minimum inhibitory concentration (MIC) of xylopin

Microorganism

Gram-positive

Staphylococcus aureus ATCC 25923 $\mathrm{MIC}(\mu \mathrm{M})$

Micrococcus luteus ATCC 10240

Bacillus subtilis ATCC 6633

Streptococcus pyogenes (CS)

Streptococcus agalactiae (CS)

Enterococcus. faecalis (CS)

Gram-negative

Escherichia coli ATCC 25922

Pseudomonas aeruginosa ATCC 27853

Stenotrophomonas maltophilia ATCC 13637

Shigella boydii (CS)

Klebsiella pneumoniae (CS)

Serratia marcescens (CS)

Enterobacter cloacae (CS)

Proteus mirabilis (CS)

Morganella morgannii (CS)

Yeast

Candida albicans ATCC 90112 
positive or negative values. Pores of different conductance levels (from 45 to $260 \mathrm{pS}$ in a $150 \mathrm{mM} \mathrm{KCl}$ solution, $\mathrm{V}_{\text {hold }} \pm 140 \mathrm{mV}$; and from $\sim 75$ to $175 \mathrm{pS}$ at $\mathrm{V}_{\text {hold }} \pm 100 \mathrm{mV}$ in a $500 \mathrm{mM} \mathrm{KCl}$ solution) were recorded in our experiments (Fig. 5).

\section{Discussion}

In this study, we have analyzed all the components in the crude venom of Xylocopa appendiculata circumvolans, a solitary bee inhabiting from Japan, by using LCESI-MS and MS/MS. It revealed that this venom contained 124 components and most of them are small peptides. The peptide sequences were further analyzed by manual analysis of their MS/MS spectra, which led to the determination of whole sequence of 58 peptides. However, most of them are related to the major peptide xylopin, having a truncated partial sequence of xylopin. Therefore, these peptides may come from cleavage of xylopin in some way, but it is not clear whether they are originally contained in the venom or not.

Most notably, these results were obtained by using only $10 \%$ of the amount of a single venom content. Among the hymenopteran insect venoms, solitary bee venom has not been extensively studied yet. One of the reasons for this may come from the difficulty of collecting a sufficient amount of venom for chemical analysis, which is due to the insect solitary life style. However, as shown in this study, the remarkable progress of mass spectrometry in sensitivity made it possible to perform this type of peptidomic analysis with so minute amount of venom. It is particularly advantageous not only for solitary bee venom but also for solitary wasp venom, and the studies along this line are in progress in our laboratory.

In addition to peptidomic analysis, we have purified and characterized the major peptide components, xylopin and xylopinin, by the conventional method. The chemical and biological characteristics of xylopin are similar to the known solitary bee venom peptides melectin and osmin - and, accordingly, this novel peptide belongs to the linear cationic $\alpha$-helical peptide group. Xylopin presented broad-spectrum antimicrobial activity, with very low hemolytic activity. Xylopin has also a Pro10 residue in the sequence, in a similar position as both melectin and osmin that present a Pro11. According to Cerovsky et al. [4], the Pro11 residue conferred to this peptide selectivity to the antimicrobial activity, as well as low hemolytic activity.

The pore formation by xylopin in artificial lipid bilayers was confirmed through electrical measurements. This is the first report of solitary bee venom peptides inducing pore formation in artificial lipid bilayers. Asolectin was employed because it is negatively charged and has shown to be a good membrane model for this class
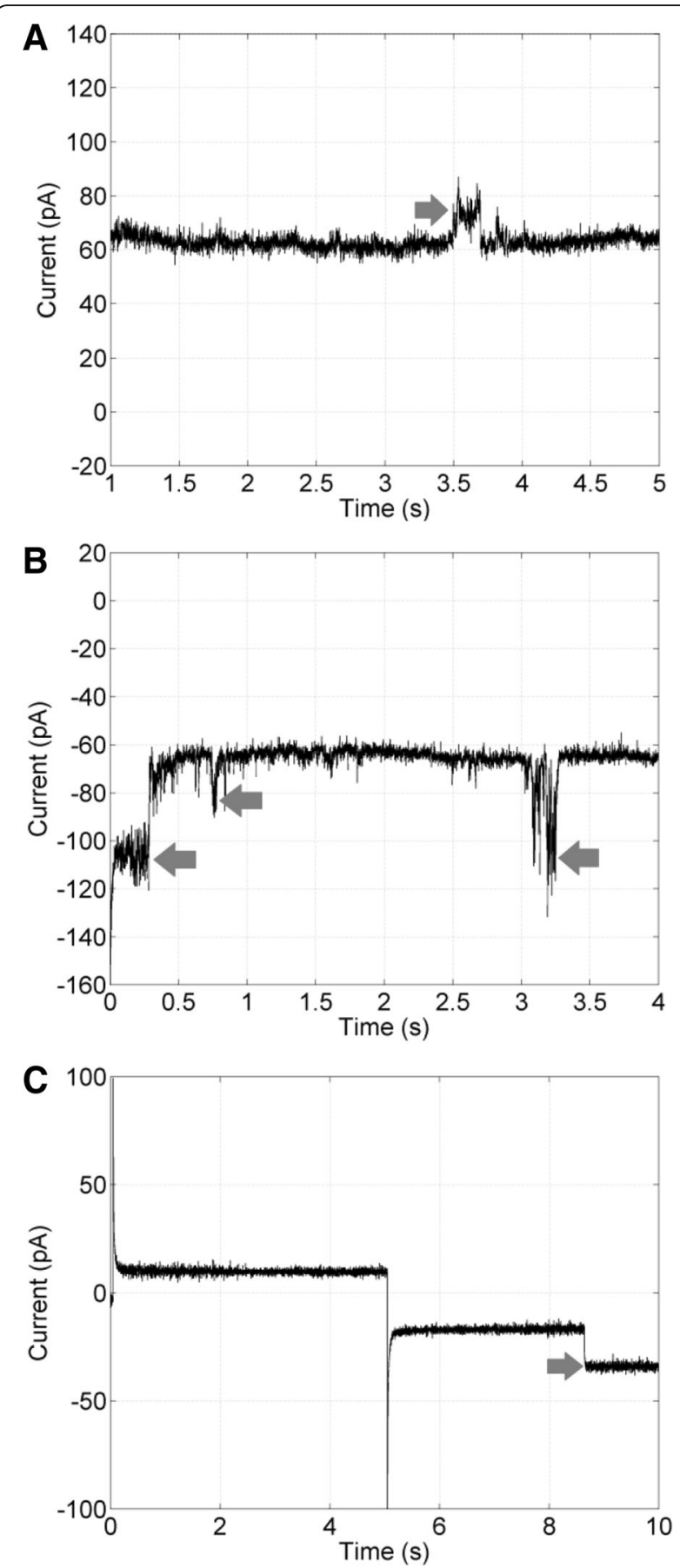

Fig. 5 Representative recordings of single channel incorporation in asolectin artificial lipid bilayers induced by xylopin at $1 \mu \mathrm{M}$ concentration. a Vhold $=+140 \mathrm{mV}$, pore conductances $=63$ and $105 \mathrm{pS}$. b Vhold $=-140 \mathrm{mV}$, pore conductance $=143$ and $259 \mathrm{pS}$. c Vhold was set at $+100 \mathrm{mV}$ for $5 \mathrm{~s}$ and was switched to $-100 \mathrm{mV}$ for the remaining $5 \mathrm{~s}$, pore conductance $=175 \mathrm{pS}$. Solutions: a and b $150 \mathrm{mM} \mathrm{KCl}$, and c $500 \mathrm{mM} \mathrm{KCl}$ (symmetrical). Arrows indicate channel apertures or closings. Four independent experiments were performed 
of peptide in previous studies [14, 24]. Conductance of the pores formed by xylopin was bigger than the conductance of the pores formed by the eumenitin-R and F, and EMP-ER and -EF from solitary wasp venoms [14]. Additionally, large conductance pores $(>500 \mathrm{pS})$ were not observed in the presence of xylopin, similarly with the eumenine mastoparan peptides EMP-ER and -EF [14], probably due to their amidated C-terminal, that would prevent cluster formation constituted by several units of the peptide.

\section{Conclusions}

LC-ESI-MS and MS/MS analysis of the crude venom extract from a solitary bee Xylocopa appendiculata circumvolans revealed the component profile of this venom, which mostly consisted of small peptides. The major peptide components, xylopin and xylopinin, were purified and characterized by the conventional technique. Their chemical and biological characteristics, belonging to linear cationic $\alpha$-helical peptides, are similar to the known solitary bee venom peptides, melectin and osmin. Pore formation in artificial lipid bilayers was demonstrated for the first time with a solitary bee peptide.

\section{Abbreviations \\ CS: Clinical sample; ES: Erythrocytes; ESI-FTMS: Electrospray ionization-Fourier transformed mass spectrometry; FTMS: Fourier transformed mass spectrometry; HPLC: High performance liquid chromatography; LC: Liquid chromatographty; LC-ESI-MS: Liquid chromatography-elctrospray ionization-mass spectrometry; MALDI-TOF MS: Matrix assisted laser desorption/ionization time-of-flight mass spectrometry; MIC: Minimal inhibitory concentration; MS: Mass spectrometry; MS/MS: Tandem mass spectrometry; OD: Optical density; SD: Standard deviation; TIC: Total ion current; TOF/TOF: Time-of-flight/time-of-flight}

\section{Acknowledgments}

KK thanks the support from JSPS KAKENHI (grant no. 15 K07805). MR thanks the support from FAPESP (grant no. 2008/00173-4) and CNPq (grant no. 473645/2012-2)

\section{Funding}

A part of this work was supported by the JSPS KAKENHI grant number 15 K07805, Grant-in-Aid for Scientific Research from the Ministry of Education, Culture, Sports, Science and Technology (MEXT) of Japan. Part of this work was supported by FAPESP (grant no. 2008/00173-4) and CNPq (473,645/2012-2).

\section{Authors' contributions}

KK (corresponding author) designed this work, prepared this manuscript and performed MS/MS analysis of the peptide sequence. KK (first author) contributed to LC-ESI-MS data acquisition and analysis. KA collected and extracted the bee samples, performed HPLC analysis and peptide synthesis. KN performed MALDI-TOF/MS analysis. XW and MK performed mast cell degranulation assay. MR and MRF designed and performed antimicrobial, hemolytic and and pore forming assay. KMY, SS and SM contributed to leishmanicidal assay. All authors read and approved the final manuscript.

\section{Ethics approval and consent to participate}

The use of mice in hemolytic assays was in agreement with the Ethical Principles in Animal Research adopted by the Brazilian College of Animal Experimentation and was approved by the Ethical Committee for Animal Research of Butantan Institute (protocol no. 459/08).

\section{Consent for publication}

Not applicable.

\section{Competing interests}

The authors declare that they have no competing interests.

\section{Publisher's Note}

Springer Nature remains neutral with regard to jurisdictional claims in published maps and institutional affiliations.

\section{Author details}

${ }^{1}$ Institute of Natural Medicine, University of Toyama, 2630 Sugitani, Toyama 930-0194, Japan. ${ }^{2}$ Faculty of Agriculture, Utsunomiya University, Utsunomiya, Tochigi, Japan. ${ }^{3}$ Immunopathology Laboratory, Butantan Institute, Sao Paulo, SP, Brazil. ${ }^{4}$ Department of Physiological Sciences, Institute of Biological Sciences, University of Brasília, Brasília, Brazil. ${ }^{5}$ Bacteriology Laboratory, Butantan Institute, Sao Paulo, SP, Brazil. ${ }^{6}$ Faculty of Pharmaceutical Sciences at Kagawa Campus, Tokushima Bunri University, Sanuki, Kagawa, Japan.

${ }^{7}$ Laboratory of Plant Resources for Medicine, Showa Pharmaceutical

University, Machidashi, Tokyo, Japan.

Received: 13 March 2017 Accepted: 18 August 2017

Published online: 29 August 2017

\section{References}

1. Banks BCE, Shipolini RA. Chemistry and pharmacology of honey-bee venom. In: Piek T, editor. Venoms of the hymenoptera. London: Academic; 1986. p. 329-416,

2. Nakajima T. Pharmacological biochemistry of vespid venoms. In: Piek T, editor. Venoms of the hymenoptera. London: Academic; 1986. p. 309-27.

3. Konno K, Kazuma K, Nihei K. Peptide toxins in solitary wasp venoms. Toxins (Basel). 2016;8(4):114

4. Čeřovský V, Hovorka O, CvaČka J, Voburka Z, Bednárová L, BoroviČková L, et al. Melectin: a novel antimicrobial peptide from the venom of the cleptoparasitic bee Melecta albifrons. Chembiochem. 2008;9(17):2815-21.

5. Stöcklin R, Favreau P, Thai R, Pflugfelder J, Bulet P, Mebs D. Structural identification by mass spectrometry of a novel antimicrobial peptide from the venom of the solitary bee Osmia rufa (hymenoptera: Megachilidae). Toxicon. 2010;55(1):20-7.

6. Čujová S, Slaninová J, Monincová L, FuČík V, Bednárová L, Štokrová J, et al. Panurgines, novel antimicrobial peptides from the venom of communal bee Panurgus calcaratus (hymenoptera: Andrenidae). Amino Acids. 2013;45(1):143-57.

7. Monincová L, Veverka V, Slaninová J, Buděšínský M, Fučík V, Bednárová L, et al. Structure-activity study of macropin, a novel antimicrobial peptide from the venom of solitary bee Macropis fulvipes (hymenoptera: Melittidae). J Pept Sci. 2014;20(6):375-84.

8. Čujová S, Bednárová L, Slaninová J, Straka J, Čeřovský V. Interaction of a novel antimicrobial peptide isolated from the venom of solitary bee Colletes daviesanus with phospholipid vesicles and Escherichia coli cells. J Pept Sci. 2014:20(11):885-95.

9. NeŠuta O, Hexnerová R, Budešínský M, Slaninová J, Bednárová L, Hadravová $R$, et al. Antimicrobial peptide from the wild bee Hylaeus signatus venom and its analogues: structure-activity study and synergistic effect with antibiotics. J Nat Prod. 2016;79(4):1073-83.

10. Favreau F, Menin L, Michalet S, Perret F, Cheneval O, Stöcklin M, et al. Mass spectrometry strategies for venom mapping and peptide sequencing from crude venoms: case applications with single arthropod specimen. Toxicon. 2006;47(6):676-87.

11. CLSI. Performance standards for antimicrobial susceptibility testing. Twentysecond informational supplement, National Committee of clinical laboratory standards. CLSI M100, S22, Ed. 22. 2011; 31(1).

12. Ortega E, Schneider H, Pecht I. Possible interactions between the Fc epsilon receptor and a novel mast cell function-associated antigen. Int Immunol. 1991;3(4):333-42.

13. Rangel M, Malpezzi ELA, Susini SMM, de Freitas JC. Hemolytic activity in extracts of the diatom Nitzschia. Toxicon. 1997:35(2):305-9.

14. Rangel M, Cabrera MPS, Kazuma K, Ando K, Wang X, Kato M, et al. Chemical and biological characterization of four new linear cationic a-helical peptides from the venoms of two solitary eumenine wasps. Toxicon. 2011:57(7-8):1081-92.

15. Takahashi M, Fuchino H, Satake M, Agatsuma Y, Sekita S. In vitro screening of leishmanicidal activity of Myanmar timber extracts. Biol Pharm Bull. 2004;27(6):921-5. 
16. Fertig N, Blick $\mathrm{RH}$, Behrends JC. Whole cell patch clamp recording performed on a planar glass chip. Biophys J. 2002;82(6):3056-62.

17. Sondermann M, George M, Fertig N, Behrends JC. High-resolution electrophysiology on a chip: transient dynamics of alamethicin channel formation. Biochim Biophys Acta. 2006;1758(4):545-51.

18. Kuhn-Nentwig L. Antimicrobial and cytolytic peptides of venomous arthropods. Cell Mol Life Sci. 2003;60(12):2651-68.

19. Wakamatsu K, Okada A, Miyazawa T, Ohya M, Higashijima T. Membranebound conformation of Mastoparan-X, a G-protein-activating peptide. Biochemistry. 1992;31(24):5654-60.

20. Hori $Y$, Demura $M$, Iwadate $M$, Ulrich AS, Niidome $T$, Aoyagi $H$, et al Interaction of mastoparan with membranes studied by $1 \mathrm{H}-\mathrm{NMR}$ spectroscopy in detergent micelles and by solid-state $2 \mathrm{H}-\mathrm{NMR}$ and $15 \mathrm{~N}-\mathrm{NMR}$ spectroscopy in oriented lipid bilayers. Eur J Biochem. 2001;268(2):302-9.

21. Sforça ML, Oyama S Jr, Canduri F, Lorenzi CCB, Pertinhez TA, Konno K, et al. How C-terminal carboxyamidation alters the biological activity of peptides from the venom of the eumenine solitary wasp. Biochemistry. 2004;43(19):5608-17.

22. Todokoro Y, Yumen I, Fukushima K, Kang SW, Park JS, Kohno T, et al. Structure of tightly membrane-bound mastoparan-X, a G-protein-activating peptide, determined by solid-state NMR. Biophys J. 2006;91(4):1368-79.

23. Wimley WC. Describing the mechanism of antimicrobial peptide action with the interfacial activity model. ACS Chem Biol. 2010;5(10):905-17.

24. Silva JC, Neto LM, Neves RC, Goncalves JC, Trentini MM, Mucury-Filho R, et al. Evaluation of the antimicrobial activity of the mastoparan Polybia-MPII isolated from venom of the social wasp Pseudopolybia vespiceps testacea (Vespidae, hymenoptera). Int J Antimicrob Agents. 2017;49(2):167-75.

\section{Submit your next manuscript to BioMed Central} and we will help you at every step:

- We accept pre-submission inquiries

- Our selector tool helps you to find the most relevant journal

- We provide round the clock customer support

- Convenient online submission

- Thorough peer review

- Inclusion in PubMed and all major indexing services

- Maximum visibility for your research

Submit your manuscript at www.biomedcentral.com/submit
Biomed Central 